\title{
COMPETITION POLICY AND INTERNATIONAL TRADE
}

\author{
James Levinsohn
}

Working Paper No. 4972

\author{
NATIONAL BUREAU OF ECONOMIC RESEARCH \\ 1050 Massachusetts Avenue \\ Cambridge, MA 02138 \\ December 1994
}

This paper was prepared for the Fairness Claims and Gains from Trade project. I am grateful to Daniel Laytin for background research assistance and W. James Adams and Ennio Stachetti for helpful discussions. I am grateful to Jagdish Bhagwati for getting me to think about the issues covered in this paper and suggesting the general topic. This paper is part of NBER's research program in International Trade and Investment. Any opinions expressed are those of the author and not those of the National Bureau of Economic Research.

(C) 1994 by James Levinsohn. All rights reserved. Short sections of text, not to exceed two paragraphs, may be quoted without explicit permission provided that full credit, including $(\mathcal{0}$ notice, is given to the source. 


\title{
COMPETITION POLICY AND \\ INTERNATIONAL TRADE
}

\begin{abstract}
This paper presents a non-technical discussion of economic issues that arise due to links between competition (or anti-trust) policy and international trade. While recent advances in international trade theory have borrowed heavily from the industrial organization literature, this work has a schizophrenic quality to it. One of the insights that motivated the new trade theory was the observation that many markets were not perfectly competitive. For the case of purely domestic markets, the industrial organization literature provided a foundation for policy advice and most countries have well established public policy regarding competition between firms. While trade theorists have borrowed heavily from the theory of industrial organization, they seem to have ignored the existence of competition policy when investigating trade policy. The two interact in important ways, and pretending that trade policy in imperfectly competitive markets takes place in the absence of any competition policy may lead to inadvertent policy outcomes.
\end{abstract}

James Levinsohn Department of Economics University of Michigan Ann Arbor, MI 48109-1220 and NBER 


\section{Competition Policy and International Trade \\ James Levinsohn \\ University of Michigan \\ National Bureau of Economic Research}

\section{Introduction}

While recent advances in international trade theory have borrowed heavily from the industrial organization literature, this work has a schizophrenic quality to it. One of the insights that motivated the new trade theory was the observation that many markets were not perfectly competitive. For the case of purely domestic markets, the industrial organization literature provided a foundation for policy advice and most countries have well established public policy regarding competition between firms. While trade theorists have borrowed heavily from the theory of industrial organization, they seem to have ignored the existence of competition policy when investigating trade policy. The two interact in important ways, and pretending that trade policy in imperfectly competitive markets takes place in the absence of any anti-trust or competition policy is akin to pretending that standard tariff policy takes place in the absence of any domestic tax structure. Just as a tariff is equivalent to a production subsidy coupled with a consumption tariff at equal ad valorum rates, analogous, although less exact, relationships surely exist between trade and competition policy. ${ }^{1}$ Ignoring these interactions may have important public policy consequences.

Policy makers and firms, at least in some instances, have been aware of the interactions between trade policy and competition policy even if economic theorists mostly neglected the issue. For example, in Korea, the government blocked a merger in a chemical industry

This paper was prepared for the Fairness Claims and Gains from Trade project. I am grateful to Daniel Laytin for background research assistance and W. James Adams and Ennio Stachetti for helpful discussions. I am grateful to Jagdish Bhagwati for getting me to think about the issues covered in this paper and suggesting the general topic.

1 For expositional ease, I will refer to what in the U.S. is commonly called anti-trust policy as competition policy. 
because that industry was subject to a 30 percent tariff, hence limiting much foreign competition. ${ }^{2}$ In the United States, the new Department of Justice Merger Guidelines (1992) make explicit reference to the role import quotas might play in determining the anti-competitive effects of horizontal mergers. In particular, foreign competition that is restricted by quotas cannot increase their U.S. sales when a merger between U.S. firms induces a price increase. This constraint on competition, as a result of trade policy, is taken into consideration by the Department of Justice Antitrust Division. Firms, too, are often aware of the role international competition has on domestic oligopolies. They frequently do not enthusiastically welcome foreign competitors in these industries. In one Asian country, the oligopolistic domestic film producers used snakes to discourage consumers from attending movie theaters showing foreign films. ${ }^{3}$ Closer to home, U.S. auto makers considered an anti-dumping suit against all foreign competitors in late 1992. This potential international trade dispute was not pursued and domestic anti-trust concerns were said to play a role in that decision.

The purpose of this paper is to begin to explore some of the interactions between competition and trade policy and to investigate both the role these interactions play when countries with differing policies trade with one another and the effects of policy harmonization. The approach of this paper is to raise what I thinl are interesting and previously neglected questions. While some intuition into probable results is posited, this paper intentionally does not provide much in the way of formal economic modelling. (Such modelling is the subject of ongoing research.) Before discussing how competition and trade policies interact, it is useful to summarize just what the policy landscape actually is. The next (second) section of this paper provides an overview of the sorts of competition policies adopted by various groups of countries. ${ }^{4}$ The third section provides a similar but more brief overview of how trade policy has been implemented in imperfectly competitive industries. In section 4, I discuss the interactions between these two sorts of policies, while

2 See Boner and Krueger, p. 13.

3 See Feketekuty, p.5.

4 This section relies heavily on background work by Daniel Laytin, and I am grateful for his superb research assistance. 
section 5 surveys issues that will arise when countries with differing competition and trade policies opt to harmonize. Conclusions are gathered in section 6 .

\section{A Survey of Competition Policies}

\section{A Taxonomy of Competition Policies}

Since I will later discuss issues surrounding harmonization of competition policies, it makes sense to first outline some to the policies actually used. Absent significant differences, the issues of harmonization are of course nute. Summarizing competition policies is tricky business, as simple taxonomies seem inadequate. Unlike trade policies which can more or less be ranked on a unidimensional scale from quite liberal to quite restrictive, competition policies are more complex. There are several ways in which competition policy is codified. Many countries use the same policy for firms that sell their products domestically and for firms that are primarily exporters. Other countries exempt exporters from domestic anti-trust legislation. Not surprisingly, the countries that exempt exporters from anti-trust legislation usually have small domestic markets. While policies vary across countries, the degree to which the policy on the books is enforced also varies a great deal. Many countries have laws on the books which simply are not enforced. Although a simple summary is sure to be somewhat incorrect, I will try to offer one anyway.

Competition policies generally fall into five groups. First, some countries have exceptionally lax and laissez faire approaches in which most anything goes in both domestic and export markets. The second approach is at the other end of the spectrum, employing exceptionally strict competition policy in both domestic and export markets. Most countries fall somewhere between these extremes. Here, a "rule of reason" is often employed. The "rule of reason" means that many actions which might decrease competition are not illegal simply because they exist, but rather courts or regulatory boards balance the effects of the anti-competitive behavior. Courts or regulators, in this case, consider the gain in profits or firm efficiency against the loss in consumer surplus that might result from anticompetitive behavior. The third group of countries employs a "rule of reason" approach

for domestic markets while employing a lax policy in export markets. The fourth group of 
countries employs a rule of reason approach in both domestic and export markets. Finally a fifth group of countries have very strict competition policies applying to domestic purely domestic industries while exporting firms are completely exempt from competition policy. To further cloud any taxonomy, within each group of policies, the degree of enforcement varies tremendously. In the remainder of this section, I review the policies of some particular countries. Most countries are not explicitly discussed, but an effort is made to review the policies of some of the most important economic players in world markets.

\section{Examples of Lax Competition Policies}

The most lax competition policies lave very little anti-trust legislation pertaining to both export and domestic markets. Examples of countries in this category inclucle Hong Kong, Taiwan, Denmark, and Italy. These countries tend to rely heavily on the market to ensure competition. As will be discussed later, though, a lax competition policy does not automatically mean that prices are oligopolistically high if the country is small and has a very liberal trade policy. For example, Hong Kong is often cited as having one of the most open trading regimes in the world. International competition, in such a case, may be sufficient to make competition policy redundant. For the case of Hong Kong, the government has passed a Code on Takeovers and Mergers, but these guidelines are simply suggestions and do not carry the force of law. ${ }^{5}$ Another Pacific Rim country, Taiwan, also has a very lax competition policy. There, most competition policy is directed at regulating the prices of several state-owned and private monopolies.

Denmark and Italy also lack comprehensive legislation concerning anti-competitive firm behavior. ${ }^{6}$ In Denmark, monopolies are neither illegal nor regulated, and while there are Government guidelines, they are enforced only through publicizing the abuses of offending firms. Italy's policy is only marginally more strict. It too has no comprehensive competition policy and the Civil Code only restricts anti-competitive behavior which harms the national interest. Since monopoly profits are argued to be in the national interest, it is a

\footnotetext{
5 See Fook-Lun Leung for details.

6 See Von Kalinowski for details.
} 
lax policy indeed. Denmark and Italy's lax policies are especially interesting since they are part of the European Community. The role of competition policy within the Community is discussed below.

\section{Examples of Policies with Differing Standards for Domestic and Export Markets}

While the above four countries' competition policies do not make distinctions between firms which produce for the domestic market or for a foreign market, this is frequently not the case. Several countries are more strict with domestic market firms, as the government recognizes the consumer's interest in low prices and a wide variety of goods. These same governments, though, also recognize that profits carned from abroad are a good thing, and exporting firms are permitted much leeway. Countries which adopt a "rule of reason" standard in assessing anti-competitive actions by firms which serve the domestic market while allowing exporting firms to pursue their own interests include the Philippines, Ireland, Germany, Greece, and Switzerland.

In Ireland, no competitively restrictive practice or trade restraint is per se illegal, rather each act is evaluated on a case-by-case basis. Mergers and acquisitions which would result in a dominant domestic market position are allowed only by consent of the Minister. While domestic market firms are generally restrained from exercising significant market power, firms which export more than ninety percent of their output are exempt from domestic standards. These firms compete in the international market free from regulation if it does not unfairly impair the domestic level of competition.

Of the countries with very distinct competition policies depending on whether the market is domestic or export, Germany is probably the most economically powerful. Domestically, German competition law appears on the surface to be relatively strict. It is, though, full of loopholes and exemptions. ${ }^{\top}$ One interesting exemption arises when a merger would allow small and medium sized firms to achieve scale economies. (It is in this same circumstance that an active trade policy is also sometimes proscribed.) Most domestic competition law in Germany is codified and does not allow for much judicial

7 See Boner and Krueger for a categorization of these loopholes and exemptions. 
discretion. The law is detailed and can be determined directly from the statutes. Merger and acquisition laws are an exception, and they are handled on a case by case basis. German competition law does allow firms to collude if their product is destined for foreign markets. In sum, German competition law for domestic firms is moderate, weighing the interests of firms and consumers. For export firms, though, the regulations are relaxed and cartelization is permitted.

\section{Japanese Competition Policy}

If summarizing the competition policies of a country in a paragraph or two is tricky business, trying to summarize Japan’s competition policy as bricty is plain crazy. Nonetheless, a summary of the competition policies of the world's larger economic players would be seriously incomplete without some mention of Japan. ${ }^{8}$. Japan's competition policy is not unlike several other countries which enforce a fairly strict policy at home yet allow collusion in export markets. There are some distinctive features of the Japanese system, though.

Beginning in the 1960's, the Japan's Anti-Monopoly Law, which had been around since 1947, began to be strengthened. Further amendments in 1977 increased the enforcement of domestic anti-trust laws. In general, domestic anti-trust law prohibits any firm activity which would "fix, maintain, or enhance prices; or limit production, technology, products, or customers or suppliers, thereby causing, contrary to the public interest, a substantial restraint of competition. ${ }^{9}$ Cartels are illegal and this law is apparently enforced. There are, though, some important exceptions. In particular, the Japanese government has the authority to grant exemptions for certain industries as well as for rationalized or depressed industries. ${ }^{10}$ While the Fair Trade Commission (FTC) oversees the enforcement of antitrust law, MITI oversees industrial policy, and it is MITI which has the power to grant exceptions to the anti-trust laws.

8 For a more detailed discussion, also see Matshusita's paper for this conference.

9 See Matsushita and Schoenbaum for details.

10 A more detailed explanation of these exceptions is found in Boner and Krueger. 
Export cartels are usually given a blanket exemption from the Anti-Monopoly law. MITI has also given several other specific sectors exemptions. These include machinery, electronics, coal mining, textiles, sugar, silk yarn, fruit, fertilizer, liquor, and perishable food. Also, joint research and development ventures are often cartelized in Japan. Indeed. it is estimated that about 20 percent of all research and development projects are cartelized horizontal ventures. ${ }^{11}$ In order to obtain MITI's permission to cartelize, a domestic industry must show that the cartel: Not violate international treaties; Not be contrary to the importer's interest; Not hurt export trade; Not be unduly discriminative; Not be unreasonably restrictive; Not unreasonably hurt domestic agriculture; and Not unreasonably hurt Japanese consumers. Clearly, these guidelines leave room for some latitude in interpretation.

The contradictions between a relatively strict domestic firm policy and a lax export firm policy creates obvious conflicts between the FTC and MITI, and while some court cases have suggested that MITI decisions can supersede the FTC, the FTC is generally perceived as doing an effective job at ensuring a competitive domestic market (although the list of exemptions is certainly non-trivial.)

An interesting aspect of Japan's competition policy which has received recent attention is that foreign companies have a very difficult time seeking protection with the anti-trust laws. This is because the FTC will only discuss Japanese firms in its rulings. Even if the foreign firm is in association with Japanese firms, it does not have standing before the FTC, so foreign firms are left without recourse. ${ }^{12}$

\section{The European Community and some Member Country Policies}

Several countries employ similar anti-trust standards for domestic and export markets. Examples of countries which use a rule of reason to judge anti-trust cases, domestic or export-oriented, include Spain, France, the Netherlands, Sweden, Belgium, as well as the European Community. In each of these countries, the government essentially considers the

11 See Boner and Krueger, page 96.

12 See Matsushita and Schoenbaum, beginning page 142 for a discussion of the how foreign firms are treated under Japan's competition laws. 
tradeoff between profits and consumer surplus when considering merger requests. There are few blanket rules, and mergers that lead to sufficiently large gains in efficiency, technological improvement, or exports may be approved if they do not infringe too much on the product choice, quality, and price to consumers.

Among EC countries, the United Kingdom has perhaps the most complex competition policy. The U.K. also has a "a manufacturing sector which is one of the most highly concentrated (if not the most highly concentrated) in the world. ${ }^{13}$ The British government has a long history of ignoring anti-competitive interactions. While British law has relied on the rule-of-reason approach, this frequently led to anti-competitive behavior. Under the Thatcher government, Britain moved toward a more strict competition policy, although the law still depended on the rule of reason to determine abuses. Nonetheless, efficiency gains from mergers are usually said to offset the loss of domestic competition, and mergers are usually allowed without too much trouble. Perhaps because its competition policy is much more lax than most other EC members, the U.K. has been unwilling to cede authority over its competition policy to the European Economic Community. EEC policy is more restrictive, and Britain may fear such a policy would place its firms at a competitive disadvantage. There seems to be little discussion regarding the presumably positive effects EEC policy would have on U.IK. consumers.

The EEC competition policy provides a nice case study in what might happen when competition policies are harmonized. EEC competition policy is based on the Treaty of Rome and it is enforced by the European Commission and the national courts of the EEC's member states. EEC competition policy is based on a rule of reason approach and represents something of a compromise between the individual policies of the member states. In practice, prior to 1990 , the Treaty of Rome competition statutes were rarely invoked and enforcement has been quite limited. In 1990, though, new regulations took effect that changed the way mergers were evaluated by lowering the levels at which a merger must be reported to the EEC. Mergers between small firms, however, need not be reported. ${ }^{14}$ An interesting conflict arises when EEC competition law is contradicted by a

13 See Grant and Utton for details.

14 See Boner and Krueger, pages 39-42 for details. 
member nation's law. A precedent has been set in the Costa/Enel case, establishing the superiority of Community Law. and this precedent has generally been accepted by member states. This issue, though, is still an emerging one and is without definite resolution at this point.

\section{North American Competition Policies}

In North America, Canada and the United States provide contrasts in competition policy. Canada, like the U.K., has a long history of lax competition law. This lax policy coupled with a small domestic market has led to a high level of firm concentration in Canada. Canada's competition law is minimal and between 1946 and 1986. no merger cases and only one monopoly case were prosecuted. ${ }^{15}$ In 1986, Canadian competition law was changed to be become rule of reason. A tribunal weighs issues of international competitiveness, economies of scale, and technical progress against the decline in domestic competition.

If Canada is especially lax, the U.S. generally lies at the other extreme. The U.S. has one of the oldest and strictest set of anti-trust laws. The Sherman Act (1890) and Clayton Act (1914) lay the foundation for U.S. competition law. The Sherman Act was enacted as a broad policy against the emerging trusts of J.P. Morgan and J.D. Rockefeller and it places severe restrictions on merger activity. The Clayton Act furthered competition law by outlawing more specific acts of anti-competitive behavior. including tying arrangements, exclusive dealing agreements, and requirements contracts. ${ }^{16}$

One of the more controversial aspects of the U.S. law is the awarding of treble damages in anti-trust suits. This has resulted in 95 percent of all anti-trust actions in the U.S. being instigated by private corporations, in contrast to other countries where the government typically initiates investigations into anti-trust abuses. Because of the very large punishment for collusion under the law, most U.S. firms opt to merge instead. These mergers are evaluated using the Department of Justice Merger Guidelines.

\footnotetext{
15 See Grant, pages 152-153 for a discussion of the Canadian law.

16 See Von Kalinowski and Grant for a summary of U.S. competition policy.
} 
Like many other countries, the U.S. allows some cartelization for export purposes, and this is covered by the Webb-Pomerene Act of 1918. This Act permits firms in a given industry to export through a single sales agency. ${ }^{17}$ While Webb-Pomerene provides protection from anti-trust laws for some export cartels, the law has not been widely exploited.

\section{Summary}

The basic trade-off that countries face in constructing their competition policies is that between firm profits and consumer welfare. When the consumers effected by collusion are not citizens, since the firms are exporters, the trade-off vanishes and the search for firm profits guides policy. There are obviously some potential problems, though, with allowing cartelizations for exports and enforcing competition in the clomestic market, and countries have taken varying approaches to dealing with this issue. One aspect of competition policy that is apparent in most of the countries surveyed is that competition policy is set at the national level and not at the industry level. That is, while some industries may obtain various exemptions, competition policy is not written separately for every industry. This is in stark contrast to international trade policy, for trade policy is typically set at the industry level. The next section provides a very brief survey of the sorts of trade policies employed in imperfectly competitive industries. Following that, we consider interactions between competition and trade policy and then discuss issues pertaining to the harmonization of competition policies.

\section{International Trade Policies in Imperfectly Competitive Industries}

The previous section outlined how competition policy is actually implemented in several countries. In this section, I outline some of the trade policy tools used throughout the world. Where competition policy was set nationally, trade policy is usually set at the industry level, hence generalizations about a specific country's trade policies are difficult and potentially misleading. A country might have very free trade in high tech sectors, but border on mercantilist when it comes to agriculture. Since I will want to consider how trade

17 See Larson and Dick for economic analyses of the Webb-Pomerene Act. 
and competition policy interact when discussing issues of harmonization. I concentrate on trade policy in imperfectly competitive industries. When industries are characterized by very many firms, each without market power, competition policy is irrelevant.

Some trade policies are simple, but these are more commonly found in international trade theory papers than in the real world. Import tariffs and export taxes or subsidies are the most straightforward policies. Whereas with perfect competition, either policy decreases economic welfare, the effects of even these simple policies are ambiguous with imperfect competition. When firms produce homogeneous products and simultaneously set quantities conditional on the quantities they expect other firms to produce, export subsidies may be welfare enhancing if enough output is sold abroad. The intuition behind this is that firms would like to produce more, since there are profits to be made. but they refrain from doing so in equilibrium since the threat to do so would not be credible conditional on the other firms' responses. An export subsidy allows the home firm to credibly produce more increasing home profits at the expense of foreign firms. One can make the case that there are not many examples of export subsidies in practice, but this is not necessarily so. While a simple payment to a firm for each unit exported or produced is not a common practice, there are more subtle ways to subsidize exports. These include special tax treatment of investment in a particular industry, government subsidized research and development, special financing available for export credits, and government loans to firms which plan to export.

While trade theory indicates that an export subsidy might be prudent public policy under very particular conditions, under other conditions economic welfare is enhanced with export taxes. In industries which produce similar but not identical products (differentiated products) and set prices as their strategic variable, an export tax might be welfare enhancing. The intuition here is that firms would like to raise prices, but decline to do so for fear that their competitors will undercut them and steal away profitable sales. An export tax allows firms to increase prices and, in some cases, both domestic and foreign firms reap higher profits (with the larger increase usually going to the firms whose government placed the export tax.) An import tariff also allows firms to reap higher profits in some cases for similar reasoning, although if the good is purchased by domestic consumers. 
their welfare declines with the higher prices they must now pay. Import tariffs and export taxes are oft-employed trade policies, although there is scant evidence that they are used in industries in which they might enhance domestic economic welfare.

Non-tariff barriers are prevalent and sometimes subtle trade policy instruments used in imperfectly (and perfectly) competitive industries. These may take the form of quotas, voluntary export restraints (VERs), product standards, government procurement policies. or other subtle forms of protection. Also, trade policies can typically be emulated by some combination of domestic tax policies. While the former is clearly under the realm of the GATT, the latter is less so. When considering harmonization of trade policies, it is useful to keep in mind that if a country really wants to maintain the protection it had when a tariff was in existence, it could agree to remove the tariff or subsidy only to replace it with the appropriate adjustment to the domestic tax code.

Another type of trade protection is found in anti-dumping law. While exact definitions of dumping vary across countries and even within a country over time, most definitions refer to selling a product in a foreign market for either less than some specified definition of cost (plus markup, in many cases) or to selling a product in a foreign market for less than it sells for in the home market. Anti-dumping law is used a great deal in the U.S. and there is evidence that it serves as a collusion-promoting device. Many anti-dumping suits are dropped either before a ruling, or, in some cases, before a suit is formally filed but after one is threatened. The result may be higher prices charged by both the foreign and competing domestic firm. Firms gain at the expense of domestic consumers.

\section{Interactions Between Trade and Competition Policy}

While the previous two sections of the paper outlined competition and international trade policy separately, neither exists absent the other and neglecting interactions between the two types of policies may provide misleading policy guidelines. Trade and competition policies typically promote competing interests. Trade policy is typically implemented to further the interests of producers. Producers are better organized than consumers and while more international trade furthers consumers interests, most trade policy is directed at restricting trade. Competition policy, on the other hand, is more directly aimed at protecting (domestic) consumer interests. As such, they may have offsetting influences. 
The plan of this section is to first discuss ways in which trade policy and competition policy interact, while the next section discusses possible implications of policy harmonization. Whereas there are exact equivalences between trade policy and domestic tax policy, interactions between trade and competition policy are fuzzier.

\section{Competition and Trade Policy for Small Countries}

When a country is economically small, the interactions between trade policy and competition policy are especially simple. If a small country maintains an open trading regime, then, in the tradeables sector, competition policy is redundant. That is. if borders are open, the fact that a domestic industry has a very high concentration of sales by a few firms should not be all that worrisome, as international competitors take the place of the minimal domestic competition. This notion has been termed the imports-as-Inarket-discipline hypothesis and it has found some validity in econometric tests. ${ }^{18}$

While this relationship between competition policy (or the lack thereof) and trade policy is theoretically straightforward, reality is usually messier. There are several caveats to keep in mind before abandoning a role for competition policy for a small open country. First, many services are not traded, so concentration in the service sector may be an appropriate target of domestic competition policy. Second, and relatedly, vertical relationships between service sectors such as banking and finance and importers may constrict international competition. For example, even if borders are open, importers frequently need to obtain credit to purchase goods. If the banks are owned by conglomerates that also own manufacturing firms which would compete with the imports, importers may have difficulty obtaining financing. Third, in a differentiated products industry, domestic firms may still have enough market power to warrant concern from the Competition Office. If the cross-price elasticity of demand for home varieties with respect to the price of foreign varieties is not very elastic, domestic firms will still be able to exert market power.

18 See "Testing the Imports-As-Market-Discipline Hypothesis" by Levinsohn. 
Competition and Trade Policy Interactions with Constant Returns to Scale Oligopolists

A general principle in considering the effects of trade policy and anti-trust policy in oligopolies is that there are few generalities. The effects of policies are very dependent on the exact market conditions to which they are applied. As already noted, whether firms set prices (Bertrand competition) or quantities (Cournot competition) in markets will effect the sign of the optimal trade policy. In the merger literature, there is a somewhat analogous result, as the welfare implications of mergers, and hence, indirectly, of competition policy, also depend on whether firms set prices or quantities. For the case in which firms produce a homogeneous product and set quantities, it is straightforward to show that with symmetric firms, linear demand, and constant returns to scale, economic welfare falls directly as industry concentration rises. A prior question is whether individual firms would find it in their interest to merge in the absence of restraints. Salant, Switzer, and Reynolds showed that in the absence of cost savings, horizontal mergers are unprofitable so long as not too much of the industry merges. The policy implication was that horizontal mergers that are observed must then be resulting in cost savings and would necessarily be socially efficient. This evocative result has been challenged and when one adds potential competition, learning, and/or returns to scale, this result may be altered.

If in a simple quantity setting framework firms do not find it profitable to merge, this is certainly not the case when firms set prices. In a framework in which firms producing related but not identical products set prices, horizontal mergers are generally profitable. This has been proven in a fairly general setting by Davidson and Deneckere. Hence, when considering the effects of competition policy, whether firms set prices or quantities matters. The exact same issue arises in considering the effects of trade policies. The predicted welfare consequences of trade or competition policies are not very robust to assumptions about how the market works and this makes it difficult to generalize about interactions between trade and competition policy. Some particular examples, though, are provided prior to a discussion of policy harmonization.

As a first example of interactions between trade and competition policy, consider the case of a country which implements a very restrictive competition policy. Firms which 
might previously have colluded or merged are now forced to compete. In a standard neoclassical economic framework. the stricter policy, absent returns to scale, learning, or other synergies, would increase economic welfare. Monopoly or oligopoly profits would shrink and consumer surplus rise by more than the decline in profits. How might trade policy alter this desirous outcome? If firms produce differentiated products, as is the case in most manufacturing industries, and compete with one another by setting prices, an export tax or import tariff has the effect of raising prices and profits at the expense of consumers. In an oligopoly, this trade policy has the effect of implicitly moving firms closer to a collusive equilibrium-exactly opposite the goal of the restrictive competition policy. Suppose, then, that a tariff or export tax is implemented as competition policy is strengthened. Then, if trade policy is not considered when competition policy is made more strict. the consumer gains to competition policy reform are diminished.

A related example occurs in the case of trade policy liberalization. Suppose GATT or other treaty obligations lead to the removal of export taxes/subsidies or import tariffs which had been leading to higher domestic industry profits at the expense of foreign firms (profit shifting.) Recall that tariffs and subsidies can take other more subtle forms. If at the same time that countries retreat from these profit shifting trade policies, they allow domestic firms to explicitly collude in international markets, the pro-competitive effects of the trade policy liberalization would be muted. Since many of the competition policies reviewed in section 2 above were marked by explicit permission to collude in export markets, this notion is not so far-fetched.

With constant returns to scale, trade policy is often directed at enabling home firms to exercise market power to shift profits away from foreign firms, while competition policy is typically directed at restricting the exercise of market power. The obvious exception is when competition policy explicitly permits export cartels. Absent this, competition policy and trade policy frequently work in opposing directions. With increasing returns to scale, though, the story is different. 


\section{Competition and Trade Policy Interactions with Increasing Returns to Scale}

When perusing competition policies. nnost countries allow mergers when there are significant efficiency gains. This would be the case with notable increasing returns to scale internal to the firm. That is, if the post-nerger firm can produce the same quantity that the pre-merger firms produced, but at lower cost, there are efficiency gains to the merger. Even the U.S., with one of the strictest competition policies, takes efficiency gains into account in its Merger Guidelines. Hence, competition policy, in the face of increasing returns to scale, tends to be less pro-competitive. Trade policy prescriptions in the presence of increasing returns to scale vary widely.

There are multiple models which generate monopolistically competitive industries and in which an active trade or competition policy would be welfare decreasing. The basic idea behind this class of models is that there are efficiency gains on the production side to having just one firm produce each variety of good, due to the increasing returns to scale, while on the consumer side, consumers benefit from the larger number of varieties available with free trade and hence from an efficient domestic production structure. In these models, tariffs or quotas are typically welfare decreasing as they raise the prices consumers pay while profits are not shifted since, due to the monopolistically competitive industry structure, competition from similar varieties drives profits to zero. A pro-competitive competition policy would force more than one firm to produce each variety, and in the presence of increasing returns to scale and/or fixed costs, this is inefficient. While an active trade or competition policy is usually welfare decreasing in this class of models, there do not appear to be obvious links between the two.

This is not the case for another industry structure, again with increasing returns to scale. If industries are characterized by increasing returns to scale and are oligopolistic, then protection may be welfare enhancing, but the benefits of an active trade policy would be counteracted if competition policy was not coordinated with the trade policy. Like most oligopolistic market structures, there are many possible cases to consider, but the intuition underlying welfare enhancing trade policies with increasing returns to scale oligopolists runs along the following lines. If an increasing returns to scale oligopolist is afforded protection against international competition, the firm finds itself able to produce more at 
a lower marginal cost. Once able to produce at this lower marginal cost, the firm may now be competitive on international markets, whereas prior to the protection, it was not. As shown by Paul Krugman, the result of the import protection is export promotion. A key element to this scenario is that once given protection, the domestic firm is allowed to expand and reap the benefits of increased efficiency. If. on the other hand, there are competition policies that place limits on the market share of the domestic firm or firms in an industry, the domestic firm will not be permitted to reap the efficiency gains, and import protection will not become export promotion. Hence, competition policy that is not coordinated with trade policy would lessen the efficacy of the trade policy.

\section{Price Discrimination and Anti-Dumping Law}

A discussion of interactions between competition policy and international trade policy would not be complete without at least some mention of the relationships between price discrimination, which is typically the domain of competition policy, and anti-dumping law, which is typically the domain of international trade policy. Further, price discrimination is only possible with market power in a domestic setting or segmented markets in a international setting.

Competition policy addresses price discrimination in various ways. In the U.S., the key piece of legislation is the Robinson-Patman Act which amended section 2 of the Clayton Act. Passed originally to protect small independent stores from the large chain grocery stores, the Act was designed to control the large powerful buyers who could exercise monopsony power. ${ }^{19}$ The law makes it illegal to "discriminate in price between purchasers of commodities of like grade and quality ... where the effect of such discrimination may be substantially to lessen competition or tend to create a monopoly..." As such, the law addresses predatory pricing more directly than run-of-the-mill price discrimination.

With the creation of a single market, Europeans may be more acutely aware of price discrimination. Nonetheless, in Europe, the gist of competition policy regarding price discrimination is similar to that in the U.S., but one must generally show that price discrimination is being practiced by a dominant producer.

\footnotetext{
19 See Neale and Goyder for a discussion of U.S. law and price discrimination.
} 
In its extreme form, what competition policy calls price discrimination, trade policy might call dumping. Again, the definitions of dumping vary across countries (and even within a country over time), but the basic idea is that it is illegal for an exporter to sell a product in a foreign market for either less than some construed cost or less than it is sold in the home market. The parallels between price discrimination and dumping are clear. If every country had strong prohibitions on price discrimination, anti-dumping law would be redundant. Further, if domestic price discrimination policy applied to exports, and if anti-dumping law really was used to address price discrimination, then the two policies would be very related, and it would be natural to attempt to coordinate them. In practice, though, it is difficult to make the case that anti-dumping law is really used to address price discrimination.

As an economic point. prohibiting price discrimination seldom makes a great deal of sense unless the price discrimination is predatory pricing in clisguise. Forcing producers to sell for one price, either domestically or internationally, may lead a profit maximizing firm to not service some markets at all and this may entail a net welfare loss. Further, alleged dumping, if it does not lead to predatory behavior, provides consumers with inexpensive goods and this is typically welfare enhancing. The punchline here is that laws prohibiting dumping (trade policy) and price discrimination (competition policy) in simple static economic models are often hard to justify on economic grounds.

\section{Harmonization of Competition Policies: Issues and Questions.}

The previous sections have outlined which competition and trade policies dominate the economic landscape and how these policies interact. In this section, I investigate some issues that arise when one considers harmonization of competition policies. In particular, as countries with different competition policies consider harmonization, what happens to the gains from trade between these countries. As the previous section suggests, there are few general answers. Rather, the particulars of the markets under consideration will matter, as well as the trade policies which co-exist with the to-be-harmonized competition policies. By discussing two examples and the concerns these stylized examples raise, the salient issues will be highlighted and, hopefully, the relevant questions posed. 
The practical importance of understanding the forces at work when harmonizing competition policies is clear. As trade policies become more integrated and coordinated, other aspects of economic policy which are not harmonized naturally receive more attention. Competition policy is no exception, and indeed in 1992, the EC Commissioner for External Economic Affairs and Commercial Policy, Sir Leon Britain argued that GATT ought to consider setting explicit rules for competition policy. ${ }^{20}$

The potential list of cases one might investigate is quite large. A general taxonomy is as follows. Countries may trade a differentiated product or they may trade homogeneous products. The former appears as intra-industry trade while the latter is more traditional Heckscher-Ohlin trade. Within a country, a good may be produced by either a perfectly competitive industry or an oligopoly. The degree of collusiveness within an oligopoly may vary with monopoly as a limiting case. The oligopolists might act simultaneously (in a Nash fashion) or one country might follow the other(s) (in a Stackelberg fashion). Also, oligopolists might set price or quantity. Competition policy might apply the same or different standards for export markets. This taxonomy, while still very incomplete, suggests dozens of permutations in which one could investigate the interactions between trade and competition policy. In most of these cases, careful analysis would require straightforward mathematical modelling. As this paper is decidedly non-technical, I model two of the very simplest cases using diagrammatic analysis.

The first case looks at international trade in a market in which one country has a very lax competition policy while another has a very strict one. I consider the case of trade in homogeneous goods, although most of the lessons will also pertain to markets in which goods are differentiated. In this context, I investigate two types of harmonization, which I label "us-like-them" and "them-like-us." The second case looks at a market in which one firm has significant market power both at home and in an export market and considers issues that arise when competition policy adopts different standards for home and export markets.

20 Cited in Feketekuty. 
Homogeneous Goods with Strict Competition Policy at Home and Lax Competition Policy Abroad

Suppose that two countries trade homogeneous goods. To make the example concrete. suppose the U.S. produces televisions and imports them from Korea. ${ }^{21}$ Suppose the U.S. enforces a strict competition policy so that economic behavior of the television industry approximates perfect competition while the Korean television industry is, due to lax competition policy, approximating a monopolist. Under these circumstances, I pose the following questions. Should the U.S. trade with Korea? Within Korea and the U.S., are consumer and producer interests coincident or opposite? Across the countries, are producer and consumer interests the same or different? If the countries decide to harmonize their policies, should the U.S. adopt an "1us-like-then" approach or a "then-like-11s" approach and what happens to the gains from international trade under each approach ?

The triptych in Figure 1 illustrates the television market in this set-up. While quite simple, it conveys many of the considerations that dominate more complicated models. The right panel illustrates the Korean demand for televisions. In this example, Korea's demand for televisions is assumed to be small relative to the U.S.'s demand for televisions. The middle panel illustrates the U.S. market for televisions. Since the U.S. is assumed to enforce competition policy, the supply of domestically produced televisions is given by a supply function which approximates marginal cost. Korea, which is assumed to have a very lax competition policy faces a demand for televisions that consists of the U.S. excess demand (U.S. demand less U.S. supply) plus Korean demand. Since Korea is assumed in this example to not enforce a competition policy, the marginal revenue perceived by Kiorean manufacturers lies below the total demand they face. One could loosely parameterize the strictness of Korea's competition policy by altering how steep this perceived marginal revenue curve is. With cartelization of the industry, it would be twice as steep, while with perfect competition it would coincide with the (linear) demand curve. With free trade, the price of televisions in Korea must equal the price in the U.S. (given the assumption of homogeneous products and abstracting from transport costs.) The price chosen by

21 The countries, policies, and goods in this example are not intended to reflect reality. They are chosen only to help with exposition. 
Korean producers to maximize profits must be such that total Korean production equals U.S. imports plus Iiorean domestic demand. This price is given by $P_{f t}$, the free trade price. At this price, the U.S. imports amount $B C$ and the gains from trade to the U.S. are $A B C$. Korean welfare is given by consumer surplus. $D E F$ in panel 1 plus pure profits $G H I J$ in panel 3. Of the pure profits, GHIJ, a fraction (FENM/GHIJ are earned in Korea with the rest being earned in the export market where FENM is seen in panel 1 and is the same height as GHIJ in panel 3 but of smaller width.

Korea's gains from trade are obtained by first drawing the marginal revenue associated with the Korean domestic demand as seen in panel 1 and super-imposing the marginal cost curve from panel 3. The difference between the consumer surplus plus profits ( $D K L M$ ) in panel 1 and the much larger areas of $D E F$ and $G H I J$ from figure 1 represent the gains from trade to Korea.

Note that Korea faces a tradeoff between the welfare of its consumer's and that of its producers. With international trade, Korean producers gain while Kiorean consumers are made worse off. While this example has considered the case of free trade, and hence the same price to consumers in the U.S. and Korea, Korea could increase its welfare if the price to the small domestic market were made lower while maintaining the higher price in the U.S. market. Free trade prevents this divergence.

Now consider the effects of harmonization of competition policies on the gains from trade and on economic welfare of each country. There are two possibilities: the "uslike-them" or "them-like-us " harmonization strategies. Suppose the U.S. adopts a lax competition policy itself in the television industry, hence allowing its domestic producers to themselves collude or at least compete less vigorously. In this case, the television market is oligopolistic as U.S. and Korean firms each recognize their ability to the market outcome. The outcome will depend on particulars of the TV market. Since we are assuming TV's are a homogeneous good, I will assume firms set quantities, for if instead they competed in prices, price would be driven to marginal cost. At this point, the simple partial equilibrium diagrams are insufficient. Nonetheless, some general lessons emerge.

If the U.S. law allowed the U.S. industry to become cartelized, the television market would be characterized by a duopoly in which the U.S. was the high cost producer. (Recall, 
the U.S. imports TV's.) The equilibrium would be one in which the U.S. would produce fewer TV's than Korea, since market shares vary inversely with marginal cost. In general, the oligopolistic equilibrium price would exceed the price that cleared the market when the U.S. market was competitive while the Korean was not. U.S. profits would increase. U.S. consumer surplus would decrease, and the U.S. would on net be hurt by an "uslike-them" policy. Due to the oligopolistic nature of the market, Korean producers would also be effected by the U.S. policy change. Korean profits would also increase. If the Korean domestic market is not too large relative to the amount of exports to the U.S., Korean welfare would actually increase with the U.S. policy change. The effect of an "us-like-them" harmonization has the (presumably unintended) effect of benefiting the U.S.'s trading partner while harming U.S. interests. It is worth remembering, though, that U.S. producers are helped by this harmonization, and producer interests often appear to dominate consumer interests in the political arena in which trade policy is formed.

Next consider the alternative approach to harmonization of competition policies-- a "them like us" approach. This would entail either regulating Korean TV manufacturers to price more pro-competitively or, if the industry was quite concentrated, breaking up the large firms. In this case, the market clearing price falls, and Korean profits fall while consumer surplus there rises. The net effect is on Korean welfare will depend on how large the export market was relative to the domestic market. If the export market was very large, the lost profits earned from American consumers do not make up for the increased Korean consumer surplus, and Korean welfare would fall. On the other hand, if the Export market was not too large, the net effect would be a welfare increase for Korea.

In the U.S., as the price of TV's falls due to strict Korean competition policy, imports rise. U.S. producers are hurt, but consumers gain even more and the gains from trade are now higher. The net effect is that both the U.S. and Korea might benefit from such a harmonization. That such a policy shift might not actually take place bears testament to the political clout of firms, as firms in both countries are harmed by the harmonization.

There are a few lessons from this simple example of harmonization. First, producer interests coincide. What is good for producers in one country proves to be beneficial to producers in the other country. This would imply that producers might agree on harmonization. Second, consumer interests also coincide. As is often the case, producer and 
consumer interests, while coincident across countries. differ within countries for both the harmonization schemes discussed. Third, when considering which competition policy to adopt from a global viewpoint, the intuition imparted by an intermediate microeconomics course provides a decent guide: global economic welfare is higher when countries harmonize to the policy which is less distorting. This suggests adopting strict competition standards, not lax ones. Put another way, two wrongs, in this case, do not make a right.

It remains to be seen whether these lessons are robust to some simple modifications of the assumptions. I next discuss some such modifications.

Suppose the U.S. had a lax competition policy, but Korea a strict policy, then, in the television industry, Korean imports would act as market discipline to U.S. firms preventing them from exerting much market power. (Again, recall Iioren is the low cost producer of TV's in this example.) This is a case in which a lax competition policy does not make much difference since free trade prevents U.S. firms from exploiting the lax policy. If harmonization led the U.S. to adopt a stringent policy, there would be very little effect. If harmonization led Korea to adopt the U.S.'s lax competition policy, we would be back in the duopolistic situation discussed above. Korean and U.S. firm profits increase as prices rise, Korea is made better off so long as its domestic market is small relative to exports and U.S. welfare falls. Again, firms agree on harmonization, as do consumers, with the former benefitting and the latter suffering. Again, global welfare is higher with a policy that leads to harmonization toward the more strict competition policy.

\section{The Case of Different Competition Policies for Export Markets}

Here, I consider the case of an exporting country that must set competition policy. As illustrated by the discussion of actual policies in Section 2, some countries have explicitly separate policies for domestic and export markets. The economic welfare implications of issues that arise in this context are considered in this subsection. The situation I consider is one in which the exporting home country sells to a foreign country that does not produce the exported good itself. So that competition policy might play a role, the market under consideration, absent regulation, is imperfectly competitive. Again to fix ideas, consider the hypothetical example of the home country (Canada) selling lumber to the foreign country (Japan.) What are the economic effects of the policy options facing Canada? 
Simplifying a complex world, Canada faces the following four options.

- 1. Regulate the domestic firm to price "competitively" at home while allowing it to operate unfettered abroad.

- 2. Enforce competition both at home and abroad.

- 3. Allow the industry to be completely umregulated both at home and abroad.

- 4. Enforce a single price, but beyond that, do not regulate.

In terms of harmonization, options 2 and 4 might be considered harmonized while 1 and 3 are not.

Figures $2 \mathrm{~A}$ and 2B present a diagrammatic analysis of these options for the simplified case of a home monopolist. Most of the results, though, are robust to the case of multiple home oligopolistic firms, although with multiple home firms, the home government will sometimes want to discourage "wasteful" competition abroad. This issue obviously does not arise with a monopolist. Another simplification in Figures $2 \mathrm{~A}$ and $2 \mathrm{~B}$ is the assumption of constant marginal costs. This assumption allows one to consider the markets independently, for with upward sloping marginal costs, output decisions in one market effect costs (and prices) in the other market. This is an important simplification. First consider option 1: regulation at home and not abroad. This is given at the top of Figure 2A. In the home market, price is set equal to marginal cost, while in the foreign market, the home firm exercises its market power and reduces exports while raising the price of those exports. Home welfare is given by consumer surplus $E F G$ and profits from the export market $A B C D$. As this is the policy adopted by many countries, consider it the benchmark case for this analysis.

If instead the home country enforces competition policy at home and abroad, the situation is given by the bottom two panels in Figure 2A. Here, price is the same at home and abroad. Global welfare is higher, as the foreign consumer surplus is now $A B C$, but the home country is worse off, as it has forfeited the profits it was previously earning. Hence, while this option is in the two countries additive best interest, the home country is worse off but by less than the foreign country gains. Why, then, do some countries enforce competition policy at home and abroad when the latter is not in their own clear interest? There are at least two possibilities, both relating the the oversimplification of 
the diagrammatic examples. First, countries do not set a competition policy for just one market and only one time. Rather, these policies are set in a repeated fashion and in multiple markets. Hence, there may be gains from policy coordination. (i.e. If you enforce competition policy for exports to my country, I will do so for firms exporting to your country. Or, if you are "nice" to me this year, I will respond in kind next year.) Furthermore, it may be difficult to segment markets effectively. That is, it may be difficult to allow collusion abroad but not at home. If the home country government has very good information on the firm(s)'s costs, this is not that large a problem. Often, though, the government does not know a firm's marginal costs. (Often the firm does not know the firm's marginal costs.) Also, it may not be in the firm in interest to truthfully reveal its costs. With imperfect information, regulation is imperfect and collusion in the foreign market may facilitate collusion at home.

This leads to option 3: no competition policy enforced at home or abroad. Here the home firm acts like a price discriminating monopolist and charges the price that maximizes its profits in each market. Unless the home and foreign demands have the same elasticity, the price charged will differ across markets with the higher being charged in the market where demand is more inelastic. The firm earns profits $A B C D$ in the foreign country as in option 1 , but it now earns profits at home also. Consumers in the home country pay a higher price than in option 1 , and relative to that benchmark, the home country is worse off by $E F G$, the deadweight loss due to monopoly at home.

The final option considers harmonization of a different sort. Here the home country firm is forced to charge the same price in both markets, but is not hindered by competition policy in setting that uniform price. This might be the case if the foreign country had an appropriately defined anti-dumping law or if the home country prohibited price discrimination. The former seems much more likely. This option is diagrammed at the bottom of Figure 2B. Total demand is the sum of each country's individual demands and is given in the right panel. The marginal revenue perceived by the firm corresponding to this demand schedule is given in this panel by $M R_{\text {Total }}$. The price. in both markets, is given by $P$. This price will necessarily lie between the two prices that would obtain with price discrimination (option 3.) Whether this policy results in a higher or lower domestic 
price, relative to price discrimination, depends on demand elasticities and is in general indeterminate. Home country welfare with this policy option may be lower than allowing the home firm to price discriminate. Again, it depends on relative demand elasticities. If foreign demand is more inelastic relative to home demand, then the profits foregone by forcing the firm to harmonize to one price will be larger. If. on the other hand, domestic demand is more inelastic, forcing harmonization could help the home country as the home market outcome moves closer to the welfare maximizing competitive outcome. From the firm's perspective, removing the option to price discriminate will never, in this set-up, increase profits. Hence, firms are likely to oppose this option.

The case for harmonization. either with option 2 or option 4 , is not a strong one in this simple world. With option 2, the home country foregoes the pure profits it could have earned abroad, while with option 4 welfare might rise or might fall, but it will not exceed the home welfare under option 1. Option 2, though, has the beneficial property that if all countries adopted this policy in all markets, global welfare would rise even though some individual players in this economy might be worse off.

\section{Caveats}

These examples are intentionally very simple. There are plenty of ways in which one might make the models more realistic and, at the same time, more complex. Almost surely, the policy implications will change with these alterations. For this reason, it is important to advertise truthfully the many ways one could amend the examples presented above. One of the most important aspects of reality ignored is the possibility of increasing returns to scale. By imposing constant returns to scale, the examples did not allow consideration of the efficiency effects of harmonization. Still, with increasing returns to scale, efficiency effects will matter to the harmonization debate much as they are important in the debate about how to set competition policy. Also, the examples were constructed around linear demand schedules and constant marginal costs. Altering the former can change results, especially in oligopoly models, while altering the latter will introduce a potentially important linkage between the home and foreign markets. Finally, the models did not consider the more reasonable alternative of oligopoly. When one considers oligopoly models, past 
experience suggests that the particular equilibrium outcome is quite sensitive the mode of market conduct (i.e. Cournot versus Bertrand, as in the merger literature discussed in the previous section), and whether the product is homogeneous or differentiated. The issues of increasing returns to scale and linearity of demands will also matter in oligopoly models. All of these cases suggest that the specific cases discussed above should be viewed as informative examples, but 110 more.

\section{Summary and Conclusions}

This paper has provided a brief international survey of countries' competition policies. It also discussed several issues that arise when competition policy is set in a world in which international trade talies place. It contends that in a global cconomy, what was once purely domestic policy realms have international implications. Just as domestic tax policy can play an important role in international trade patterns, competition policy also has important international implications. Some issues only arise in an international context. For example, should governments enforce competition policy in export markets? Other issues have traditionally arisen in a domestic context but also have implications for international trade. For example, does a strict competition policy which is sound economic policy in a closed economy still make for good policy when a country's trading partners have a very lax competition policy? There are few general issues, but one message is clear. There are important linkages between competition policy and international trade and ignoring one or the other may result in misguided policy. There are many unanswered questions and it is hoped that this paper will motivate others to begin to examine these important linkages. 


\section{References}

Bhagwati, Jagdish (1992) "Fair Trade Reciprocity and Harmonization: The New Challenge to the Theory and Policy of Free Trade," Columbia University, mimeo.

Boner, Roger and Reinald Krueger (1991) "The Basics of Antitrust Policy," World Bank Technical Paper Number 160, The World Bank, Washington, D.C..

Deneckere, Raymond and Carl Davidson ( Winter, 1985) "Incentives to form coalitions with Bertrand competition," Rand Journal of Economics, 16, 473-486.

Dick, Andrew (1991) "Are Export Cartels Efficiency Enhancing or Monopoly Promoting?," UCLA Working Paper, No. 610.2.

Farrell, Joseph and Carl Shapiro (March, 1990) "Horizontal Mergers: An Equilibrium Analysis," American Economic Review, 80, 107-126.

Feketekuty, Geza (1993) "Reflections on the Interactions Between Trade policy and Competition Policy," mimeo, OECD Trade Committee.

Fook-Lun Leung, Frnakie (1991) "Hong Kong," in Competition Laws of the Pacific Rim Countries, ed. Von Kalinowski, Julian. New York: Bender.

Grant, Wyn (1989) Government and Industry: A Comparative Analysis of the U.S., Canada, and the UK. Hants: Elger.

Larson, David (1970) "An Economic Analysis of the Webb-Pomerene Act," Journal of Law and Economics, 13, 461-500.

Laytin, Daniel (1993) "National Antitrust Laws," mimeo, University of Michigan.

Levinsohn, James (1993) "Testing the Imports-As-Market-Discipline Hypothesis," Forthcoming in the Journal of International Economics.

Matsushita, Mitsuo and T. Schoenbaum (1989) Japanese International Trade and Investment Law. Tokyo: University of Tokyo Press.

Neale, A.D. and D.G. Goyder (1982) The Antitrust Laws of the U.S.A.. Cambridge: Cambridge University Press.

Salant, Stephen, and S. Switzer and R. Reynolds ( May, 1983) "Losses from Horizontal Mergers: The Effects of an Exogenous Change in Industry Structure On Cournot Nash Equilibrium," Quarterly Journal of Economics, XCVII, 185-199.

Willig, Robert (1991) "Merger Analysis, Industrial Organization Theory, and Merger Guidelines," Brookings Papers: Microeconomics, , 281-332.

U.S. Department of Justice (1992) "Merger Guidelines," 1992 version.

Von Kalinowski, Julian (1987) Overview: World Competition Law. New York: Matthew Bender. 

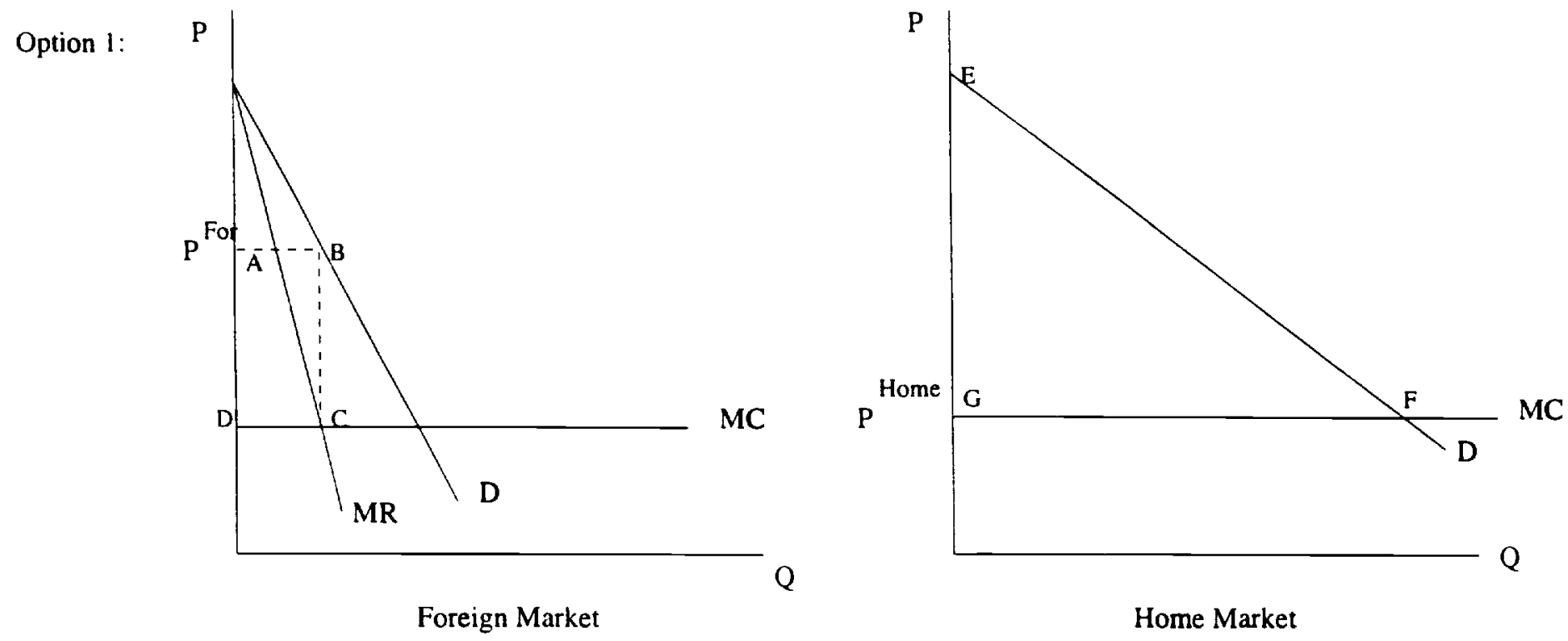

Foreign Market

Home Market
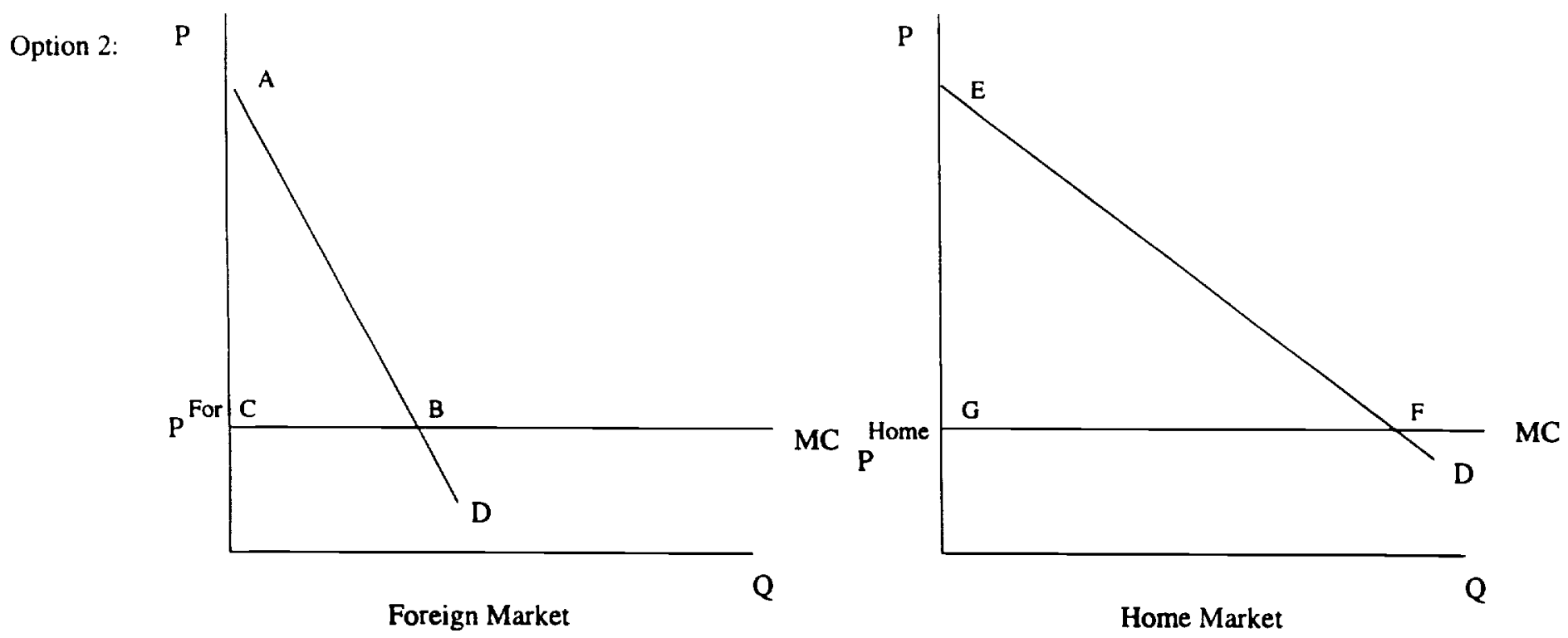

Figure 2A 


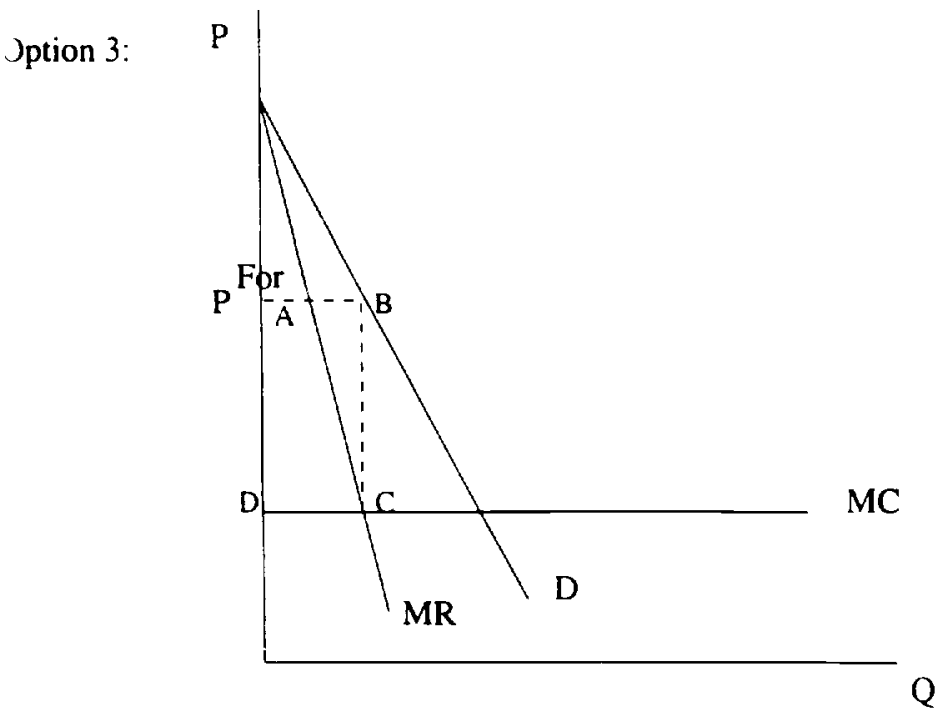

Foreign Market

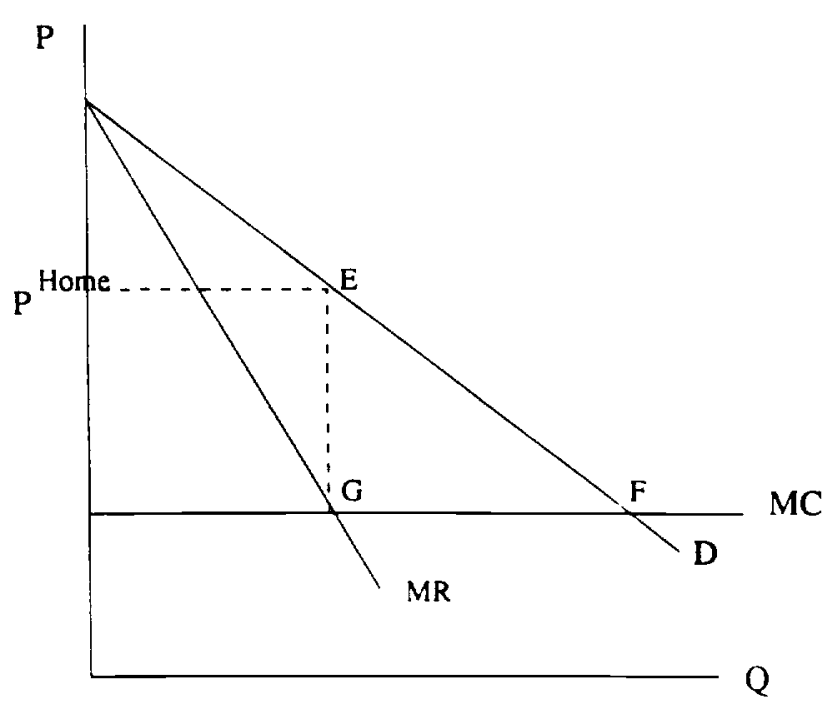

Home Market

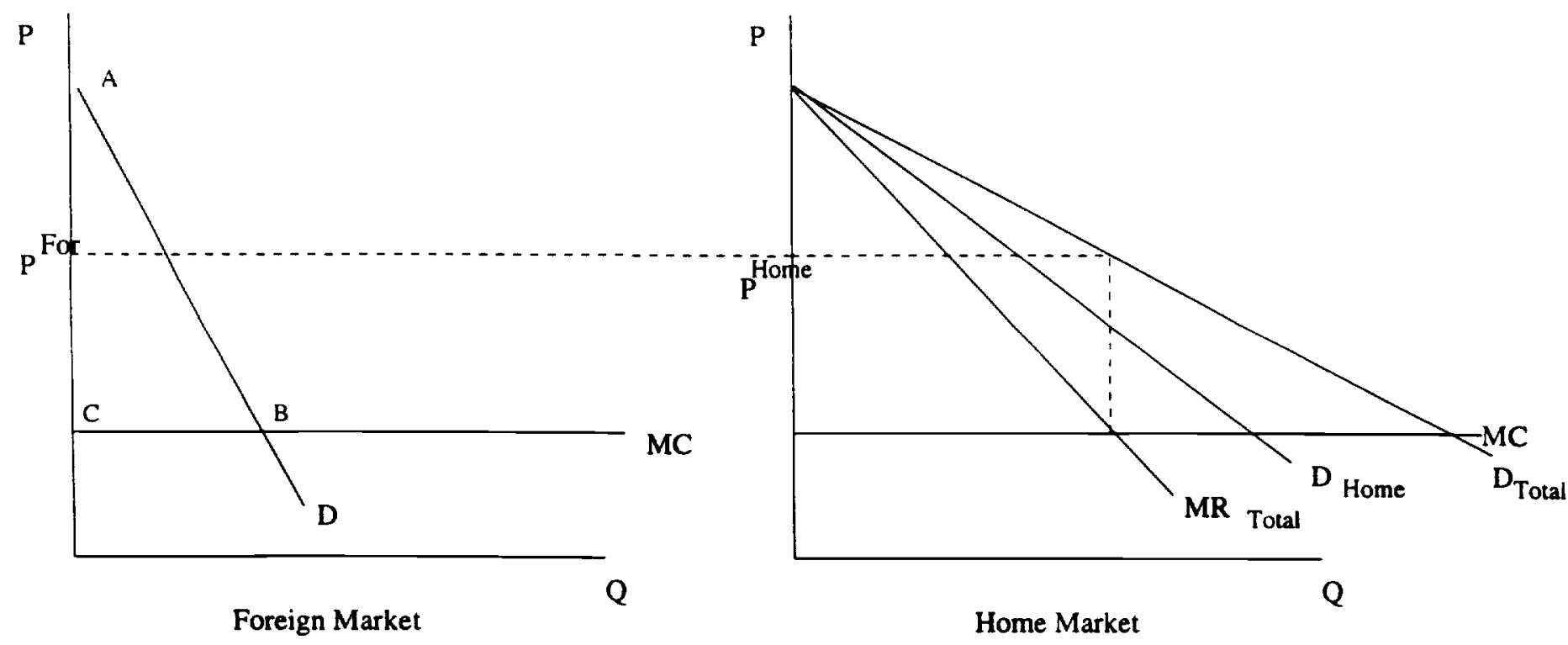

Figure 2B 